\title{
Madame de STAËL, Réflexions sur le procès de la reine, présenté et annoté par Monique Cottret, Paris, Les Éditions de Paris, 2006, 126 pages.
}

\section{Dominique Godineau}

\section{(2) OpenEdition}

Journals

Édition électronique

URL : https://journals.openedition.org/clio/4872

DOI : 10.4000/clio.4872

ISSN : 1777-5299

Éditeur

Belin

Édition imprimée

Date de publication : 1 novembre 2006

Pagination : 319-348

ISBN : 2-85816-867-9

ISSN : $1252-7017$

Référence électronique

Dominique Godineau, « Madame de STAËL, Réflexions sur le procès de la reine, présenté et annoté par Monique Cottret, Paris, Les Éditions de Paris, 2006, 126 pages. », Clio. Histoire, femmes et sociétés [En ligne], 24 | 2006, mis en ligne le 03 octobre 2007, consulté le 24 avril 2022. URL : http:// journals.openedition.org/clio/4872 ; DOI : https://doi.org/10.4000/clio.4872

Ce document a été généré automatiquement le 24 avril 2022

Tous droits réservés 


\title{
Madame de STAËL, Réflexions sur le procès de la reine, présenté et annoté par Monique Cottret, Paris, Les Éditions de Paris, 2006, 126 pages.
}

\author{
Dominique Godineau
}

En ces temps où, dans la production éditoriale comme au cinéma, Marie-Antoinette est à la mode, il faut absolument s'arrêter sur cet ouvrage. Le titre exact de ce court pamphlet (30 p.), publié anonymement en août 1793 après le renvoi de MarieAntoinette devant le Tribunal révolutionnaire, est Réflexions sur le procès de la reine PAR UNE FEMME. Et c'est aux femmes que l'auteure s'adresse en premier, aux « femmes de tous les pays, de toutes les classes de la société »: sensibles, elles ne peuvent qu'être émues par les malheurs de la reine; mères, elles seraient «immolées toutes dans une mère si tendre ». Au personnage public de la reine, à la femme de pouvoir active en politique, Mme de Staël oppose en effet le portrait d'une mère aimante et charitable, cible de "ce genre de calomnies dont il est si facile de flétrir toutes les femmes », qui n'aurait pourtant «causé le malheur de personne » et ne serait intervenue dans les affaires publiques qu'en amie de la liberté. Le texte de Mme de Staël est bien connu et l'intérêt de cette réédition tient pour beaucoup à l'éclairante présentation de Monique Cottret.

2 Une utile introduction souligne que l'image actuelle de Marie-Antoinette est une projection de notre époque, et replace le texte dans le contexte révolutionnaire. Remarquablement écrit, réflexive et informative (grand intérêt des notes et de la chronologie finale), la longue postface tient à la fois de l'essai et de l'analyse de texte particulièrement réussie. Monique Cottret y croise trois axes (la reine, Mme de Staël, la Révolution), qu'elle décline selon les trois temps qui, remarque-t-elle, structurent les Réflexions : «le passé recomposé, le présent redouté, l'éternité rêvée " (signalons au passage de très belles pages sur le temps en Révolution). S'appuyant sur nombre d'études et de documents ${ }^{1}$, elle pointe les confusions et oublis volontaires, les 
réécritures qui permettent à Mme de Staël de faire disparaître Madame Déficit, Madame Veto, l'Autrichienne, derrière l'image idéalisée de la mère souffrante et courageuse. Par cette confrontation entre le texte et l'analyse des faits, Monique Cottret esquisse les deux portraits, tout en finesse et historicisés, de la reine et de son avocate. En comparant ensuite les Réflexions à d'autres textes, du même auteur (Considérations...) ou d'autres (Robespierre, Châteaubriant...), elle dégage les conceptions de Mme de Staël sur la Révolution et ouvre le débat sur la Terreur. L'épilogue rappelle que c'est aussi en «mère coupable» (de prétendu inceste) que la reine fut jugée. Au final: un "petit livre » à plusieurs entrées, que l'on lira avec profit et plaisir.

3 Signalons aussi : Annie Duprat, Marie-Antoinette, une reine brisée, Paris, 2006.

\section{NOTES}

1. En particulier l'édition par Evelyne Lever de Marie-Antoinette, correspondance

(1773-1798), Paris, 2005. 